\title{
INFLUENCE OF THERMAL MODIFICATION ON THE PHYSICAL AND MECHANICAL PROPERTIES OF Eucalyptus badjensis MIXED PARTICLEBOARD / OSB PANELS
}

\author{
Giuliano Ferreira Pereira ${ }^{1 *}$, Setsuo Iwakiri ${ }^{1}$, Rosilani Trianoski ${ }^{1}{ }^{1}$ Polliana D'angelo Rios ${ }^{2}$, Renan Zunta Raia ${ }^{1}$ \\ ${ }^{1}$ Universidade Federal do Paraná, Programa de Pós-graduação em Engenharia Florestal, Curitiba, Paraná, Brasil - giuliano.giiu @ gmail.com; \\ setsuo.ufpr@gmail.com; rosillani@gmail.com; renanraia@gmail.com \\ ${ }^{2}$ Universidade do Estado de Santa Catarina, Programa de Pós-graduação em Engenharia Florestal, Lages, Santa Catarina, Brasil - \\ polliana.rios@udesc.com
}

Received for publication: 27/09/2019 - Accepted for publication: 09/06/2020

\begin{abstract}
Resumo
Influência da modificação térmica nas propriedades físicas e mecânicas de painéis mistos de MDP/OSB de Eucalyptus badjensis. Essa pesquisa teve como objetivo avaliar os efeitos da aplicação da modificação térmica, em diferentes temperaturas e tempos de exposição, sobre as propriedades tecnológicas de painéis mistos MDP/OSB de Eucalyptus badjensis. Utilizando a madeira de Eucalyptus badjensis, foram produzidos painéis MDP, OSB e mistos MDP/OSB (testemunhas e modificados termicamente). A modificação térmica dos painéis mistos foi realizada em três temperaturas $\left(180^{\circ} \mathrm{C}, 200^{\circ} \mathrm{C}\right.$ e $\left.220^{\circ} \mathrm{C}\right)$ e dois tempos de exposição $(10$ minutos e 12 minutos). Para a produção dos painéis, foram utilizados $6 \%$ de adesivo fenol-formaldeído e $1 \%$ de parafina. Foram avaliadas as propriedades de absorção de água e inchamento em espessura após 2 e 24 horas de imersão, além do módulo de elasticidade, módulo de ruptura e tração perpendicular à superfície dos painéis. Os resultados permitiram concluir, que a modificação térmica apresentou influência positiva sobre a maior parte das propriedades físicas. Entre os diferentes tempos de exposição estudados, o mais efetivo foi o de 12 minutos, em especial para na absorção de água após 2 horas em que ocasionou uma redução de 11,27\% em relação aos testemunhas. Por sua vez, a temperatura mais efetiva foi a de $220^{\circ} \mathrm{C}$, com destaque para o inchamento em espessura após 24 horas, em que ocasionou um decréscimo de $23,76 \%$ quando comparado com os painéis testemunhas. Para as propriedades mecânicas, a modificação térmica nos tempos de exposição e temperaturas estudados, não influenciou os resultados dos painéis mistos MDP/OSB.

Palavras-chave: Tratamento térmico, Tempos, Temperaturas
\end{abstract}

\section{Abstract}

The objective of this research was to evaluate the effects of thermal modifications, at different temperatures and exposure times, on the technological properties of mixed particleboard / OSB panels made out of Eucalyptus badjensis. Using the wood of Eucalyptus badjensis, Particleboard, OSB and mixed Particleboard/OSB panels (control and thermally modified) were manufactured. The mixed panels' thermal modification was carried out under three temperatures $\left(180^{\circ} \mathrm{C}, 200^{\circ} \mathrm{C}\right.$ and $\left.220^{\circ} \mathrm{C}\right)$ and two exposure times $(10$ minutes and 12 minutes). For the panels' manufacturing, $6 \%$ of phenol-formaldehyde adhesive and $1 \%$ of paraffin were employed, which was calculated based on the particles' dry mass. The water absorption and thickness swelling properties were evaluated after 2 and 24 hours of immersion, in addition to the panels' modulus of elasticity, modulus of rupture and internal bond. Based on the results, we were able to conclude that the thermal modification affected most of the physical properties positively. From the different exposure times studied, the most effective one was the period of 12 minutes, especially for water absorption after 2 hours, which caused a reduction of $11.27 \%$. In turn, the most effective temperature was of $220^{\circ} \mathrm{C}$, highlighting the thickness swelling after 24 hours, which caused a swelling decrease of $23.76 \%$ in comparison with the control panels. Regarding the mechanical properties, the thermal modification, in terms of the studied exposure times and temperatures, did not affect the results of the mixed particleboard /OSB panels.

Keywords: Thermal treatment, Times, Temperatures.

\section{INTRODUCTION}

The species Eucalyptus badjensis Beuzev. \& Welch is very promising for commercial plantations in Brazil, mainly due to its high resistance to frosts and rapid growth, which can reach over 4 meters high in four years. It is especially indicated for high-altitude locations, such as the Santa Catarina Plateau and Southern Paraná (HIGA et al., 2002; SANTOS et al., 2015). The species' wood usage has been studied for several products, such as: cellulose pulp, paper and particleboard panels (PEREIRA et al., 2017).

Particleboards are manufactured all around the world. In Brazil, the particleboard production of 2018 totaled 3.24 million $\mathrm{m}^{3}$, putting the country among the top eight greatest particleboard world producers (IBÁ, 2019). This type of panel can be used in cladding systems, floors, doors and others (Marzbani et al., 2015). However, particleboards do not meet the strength requirements required for structural purposes.

FLORESTA, Curitiba, PR, v. 51, n. 2, p. 419-428, abril/jun 2021.

Pereira, G. F. et.al.

ISSN eletrônico 1982-4688

DOI: $10.5380 /$ rf.v51 i2. 69403 
A type of panel widely used for structural purposes is the OSB. Generally, this product is used on walls, beams and other structures (PRESTEMON et al., 2015). In Brazil, the OSB production is incipient, with only one production unit, located at the city of Ponta Grossa - PR (GORSKI et al., 2015).

In comparison with particleboards, OSB panels have better mechanical resistance properties, but a lower surface finishing (THOEMEN, IRLE, SERNECK, 2010). Thus, an alternative to obtaining a structural product with adequate mechanical resistance and better surface finishing would be manufacturing mixed panels using sliver-type particles in the outer layers (particleboards) and strand-type particles in the core layer (OSB).

The major limitation of OSBs and particleboards is the high percentage of water absorption and thickness swelling. Consequently, several studies have been carried out to improve these panels' dimensional stability. One method that has been proven efficient is thermal modification (MELO et al., 2008; MENDES et al., 2013).

Thermal modification consists of heating wood products at temperatures ranging from $100^{\circ} \mathrm{C}$ to $260^{\circ} \mathrm{C}$ (CROITORU et al., 2018). This method has been widely studied and industrially applied in Europe. Nowadays, in Brazil, researches on this topic gained prominence, but they remain incipient (BATISTA et al., 2019). The level of transformation to which the wood constituents are subject and the effects attributed to thermal modification are highly affected by factors such as: temperature, exposure time, heating rate and the interaction with the species employed. And just like thermal modification increases the material's quality, high temperatures and exposure times can result in mass loss, which can decrease the product's quality. Thus, the variables of the thermal modification process must be optimized in order to maximize the benefits and reduce any loss to the panel's quality (PONCSAK et al., 2006).

In this context, several studies have been carried out with the purpose of analyzing the thermal modification process' variables in wooden panels and, especially, evaluating different exposure times and temperatures.

For OSB, Del Menezzi et al. (2009) evaluated the behavior of commercial Pinus taeda panels treated at temperatures of $190^{\circ} \mathrm{C}$ and $220^{\circ} \mathrm{C}$ for periods of 12,16 and 20 minutes. The results prove that different exposure times and thermal modification temperatures improve the panels' dimensional stability, while only the treatment at $220^{\circ} \mathrm{C}$ promoted a reduction of the modulus of elasticity values.

For particleboard, Melo et al. (2018) studied Eucalyptus spp. subjected to thermal modification at temperatures of $160^{\circ} \mathrm{C}$ and $180^{\circ} \mathrm{C}$ for periods of 6 and 12 minutes. The results indicated that the treatments reduce water absorption and that the treatment at a temperature of $180^{\circ} \mathrm{C}$ for 6 minutes presents the best performance.

Based on the above, this study's objective was to evaluate the effect of thermal modification at 3 temperatures and 2 exposure times on the physical and mechanical properties of mixed particleboard / OSB panels manufactured with an alternative species, Eucalyptus badjensis.

\section{MATERIAL AND METHODS}

The experimental phases of this research are exhibited in figure 1.

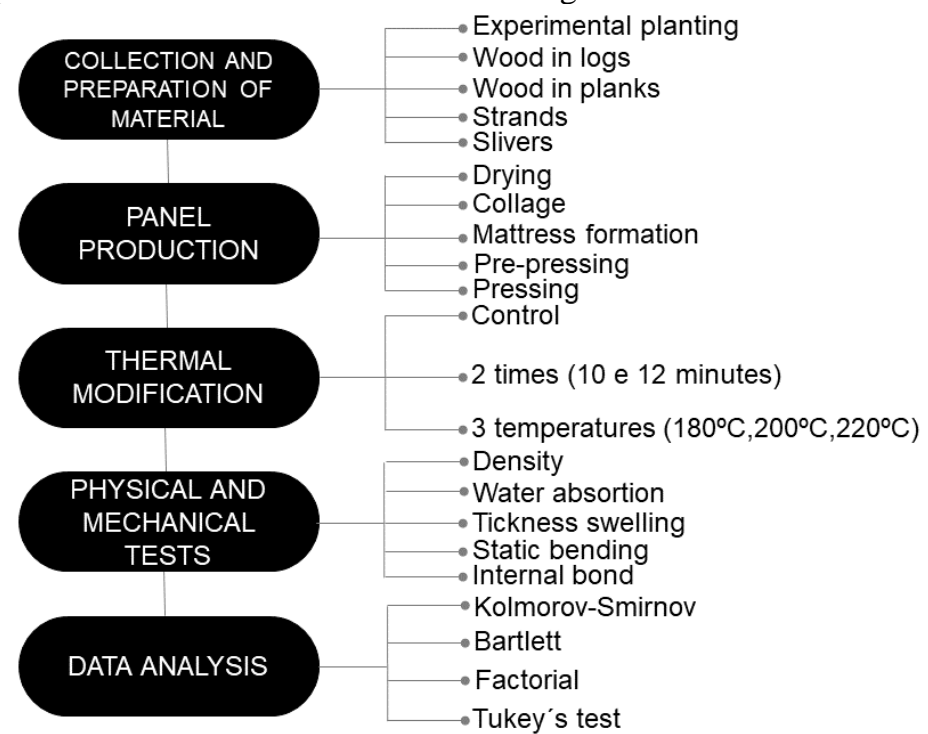

Figure 1. Chart of the experimental phases

Figura 1. Organograma das fases experimentais

FLORESTA, Curitiba, PR, v. 51, n. 2, p. 419-428, abril/jun 2021. 
To perform the study, Eucalyptus badjensis wood from a 10-year-old experimental plantation, located in the city of Lages - SC, was employed. The trees were felled and cut into 2-meter logs. Then, the material was transported to a sawmill in the municipality of Otacílio Costa - SC, where it was turned into 1-inch-thick boards and sent to the study facility.

At the study facility, the boards were cut into pieces of approximately $90 \mathrm{~mm}$ wide and $150 \mathrm{~mm}$ long and then turned into strands that were sieved through a 9.52-millimeter sieve to remove smaller particles. In a hammer mill, part of the strand-type particles (Figure 2b) was turned into sliver-type particles (Figure 2a). Subsequently, this material was sieved for the removal of fine particles, using 8-and 30-mesh sieves, with 2.36-and 0.6-millimeter openings, respectively. The average length of the Eucalyptus badjensis particles was of $10.50 \mathrm{~mm}$ for slivers and $78.29 \mathrm{~mm}$ for strand particles.

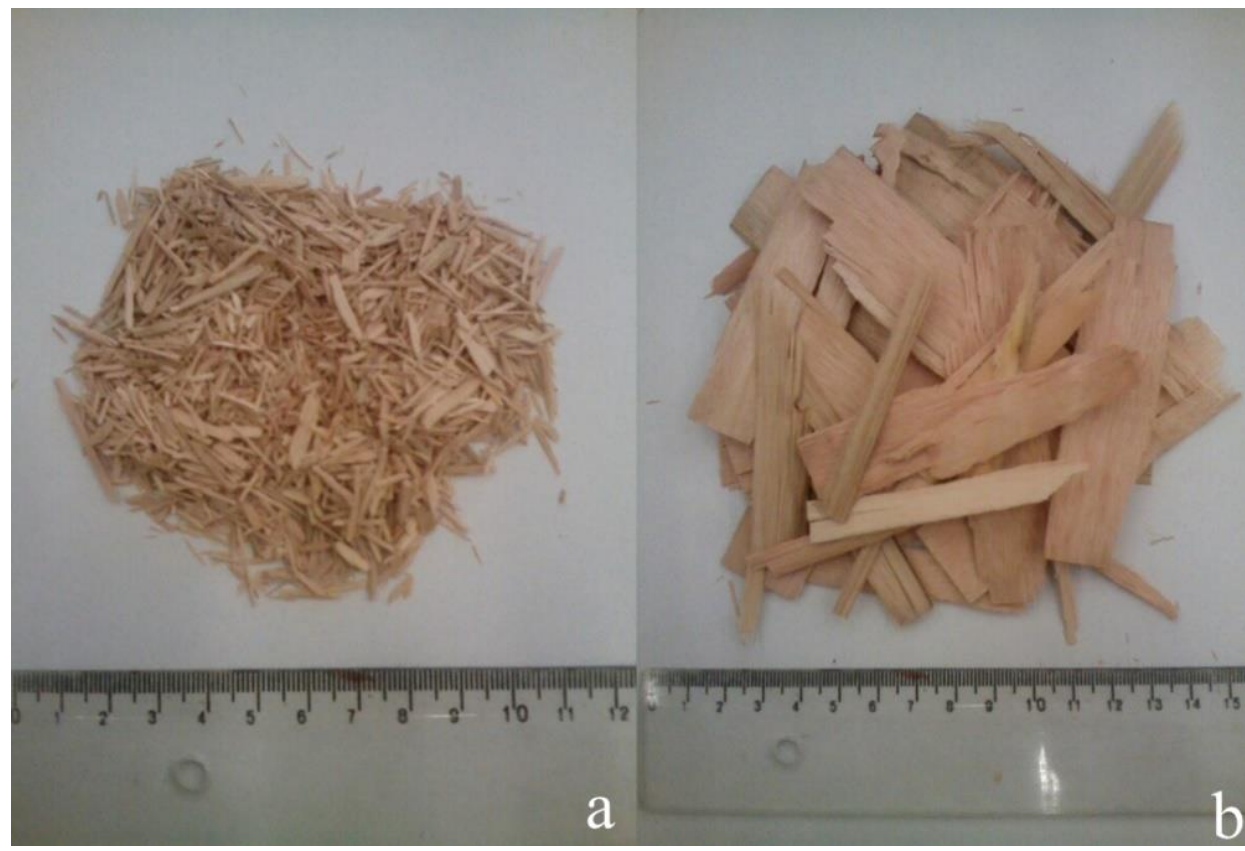

Figure 2. Eucalyptus badjensis particles. a) slivers b) strands

Figura 2. Partículas de Eucalyptus badjensis. a) slivers b) strands

For the panel manufacture, the particles were dried in an oven at the average moisture content of $4 \%$ and taken to a glue machine for the application of $1 \%$ paraffin and $6 \%$ phenol-formaldehyde resin, with a solids content of $53.00 \%$ and viscosity of $492 \mathrm{cP}$. For the mattress manufacturing and pre-pressing, the particles were randomly arranged in a forming box at the proportion of $10 \%$ sliver / 80\% strand / 10\% sliver layers. This percentage was selected based on preliminary studies that indicate that this composition results in the best performance for physical and mechanical properties.

Subsequently, the particle mattress was pressed at the temperature of $180^{\circ} \mathrm{C}$, the specific pressure of 4.0 $\mathrm{MPa}$ and the pressing time of 8 minutes. The panels were implanted with the dimensions of $48 \mathrm{~cm} \times 48 \mathrm{~cm} \times 1.3$ $\mathrm{cm}$ and nominal density of $0.900 \mathrm{~g} / \mathrm{cm}^{3}$ in the outer layers and $0.700 \mathrm{~g} / \mathrm{cm}^{3}$ in the core layer. The density was calculated based on the dry mass and the panel's dimensions. After pressing, the panels were squared and airconditioned at the temperature of $20 \pm 2^{\circ} \mathrm{C}$, relative humidity of $65 \pm 5 \%$ and average moisture content of $12 \%$ until their stabilization.

After their acclimatization, the panels were thermally modified in a hot press, according to the experimental plan presented in table 1. Three panels were used in each treatment. The exposure times and temperatures were determined based on studies on the effects of thermal modification on particleboards and OSB panels, such as Del Menezzi et al. (2009), Mendes et al. (2013) and Melo et al. (2018), whose objective was to improve the panels' dimensional stability while consuming the minimal amount of energy as possible.

FLORESTA, Curitiba, PR, v. 51, n. 2, p. 419-428, abril/jun 2021. 
Table 1. Experimental design

Tabela 1. Plano experimental

\begin{tabular}{lll}
\hline Treatment & $\begin{array}{l}\text { Time } \\
\text { (Minutes) }\end{array}$ & $\begin{array}{l}\text { Temperature } \\
\left({ }^{\circ} \mathbf{C}\right)\end{array}$ \\
\hline Control & - & - \\
$10 \mathrm{~min} / 180^{\circ} \mathrm{C}$ & 10 & 180 \\
$12 \mathrm{~min} / 180^{\circ} \mathrm{C}$ & 12 & 180 \\
$10 \mathrm{~min} / 200^{\circ} \mathrm{C}$ & 10 & 200 \\
$12 \mathrm{~min} / 200^{\circ} \mathrm{C}$ & 12 & 200 \\
$10 \mathrm{~min} / 220^{\circ} \mathrm{C}$ & 10 & 220 \\
$12 \mathrm{~min} / 220^{\circ} \mathrm{C}$ & 12 & 220 \\
\hline
\end{tabular}

For the analysis of the physical and mechanical properties, five specimens were removed from each panel for density tests, five for water absorption and thickness swelling after 2 and 24 hours of immersion in water, four for static bending and five for internal bond. The tests were conducted according to the procedures described by the European standards EN 323 (2002), EN 317 (2006), EN 319 (2006) and EN 310 (2006), respectively.

The results were subjected to the Kolmorogorov-Smirnov and Bartlett tests to verify the data's normality and homogeneity, respectively. The effect of using different temperatures and times of thermal modification was evaluated by means of a $3 \times 2$ factorial analysis (Temperatures x Exposure times). Since the data analysis revealed no interaction between different times and temperatures, the data were analyzed separately. All treatments were submitted to Tukey's test at the $95 \%$ confidence level.

\section{RESULTS}

The results of density and compaction ratio of the panels submitted to different times of thermal modification are exhibited in Table 2.

Table 2. Mean values of apparent specific mass and compaction ratio of panels subjected to different thermal modification periods.

Tabela 2. Valores médios de densidade aparente e razão de compactação dos painéis submetidos a diferentes tempos de modificação térmica.

\begin{tabular}{lll}
\hline Time & Density $\left(\mathbf{g} / \mathbf{c m}^{\mathbf{3}}\right)$ & Compaction ratio \\
\hline Control & $0.717 \mathrm{a}(5.18)$ & $1.42 \mathrm{a}(5.18)$ \\
10 minutes & $0.713 \mathrm{a}(5.88)$ & $1.41 \mathrm{a}(5.88)$ \\
12 minutes & $0.713 \mathrm{a}(5.91)$ & $1.41 \mathrm{a}(5.91)$ \\
\hline
\end{tabular}

Means followed by the same letters in the same column are not statistically different according to Tukey's test at a 95\% probability level. Coefficient of variation, in percentage, in parentheses.

As seen in Table 2, the exposure times to thermal modification had no significant effect on density and compaction ratio.

The results of apparent density and compaction ratio of the panels subjected to different temperatures of thermal modification are exhibited in table 3.

Table 3. Mean values of density and compaction ratio for panels subjected to different thermal modification temperatures.

Tabela 3. Valores médios de densidade aparente e razão de compactação dos painéis submetidos a diferentes temperaturas de modificação térmica.

\begin{tabular}{lll}
\hline Temperature & Density $\left(\mathbf{g} / \mathbf{c m}^{3}\right)$ & Compaction ratio \\
\hline Control & $0.717 \mathrm{a}(5.18)$ & $1.42 \mathrm{a}(5.18)$ \\
$180^{\circ} \mathrm{C}$ & $0.716 \mathrm{a}(5.64)$ & $1.42 \mathrm{a}(5.64)$ \\
$200^{\circ} \mathrm{C}$ & $0.720 \mathrm{a}(5.24)$ & $1.43 \mathrm{a}(5.24)$ \\
$220^{\circ} \mathrm{C}$ & $0.701 \mathrm{a}(6.34)$ & $1.39 \mathrm{a}(6.34)$ \\
\hline
\end{tabular}

Means followed by the same letters in the same column are not statistically different according to Tukey's test at a 95\% probability level. Coefficient of variation, in percentage, in parentheses.

FLORESTA, Curitiba, PR, v. 51, n. 2, p. 419-428, abril/jun 2021. 
According to the data in table 3, the thermal modification temperatures did not affect the panels' density and compaction ratio. The results of water absorption and thickness swelling after 2 and 24 hours of water immersion of the panels subjected to thermal modification at different temperatures are exhibited in table 4.

Table 4. Mean values of water absorption and thickness swelling for panels subjected to different thermal modification times.

Tabela 4. Valores médios de absorção de água e inchamento em espessura para painéis submetidos a modificação térmica em diferentes tempos.

\begin{tabular}{lllll}
\hline Time & $\begin{array}{l}\text { WA2h } \\
(\boldsymbol{\%})\end{array}$ & $\begin{array}{l}\text { WA24h } \\
(\mathbf{\%})\end{array}$ & $\begin{array}{l}\text { TS2h } \\
(\boldsymbol{\%})\end{array}$ & $\begin{array}{l}\text { TS24h } \\
(\boldsymbol{\%})\end{array}$ \\
\hline Control & $13.93 \mathrm{~b}(10.66)$ & $46.15 \mathrm{~b}(11.88)$ & $5.16 \mathrm{a}(28.47)$ & $14.69 \mathrm{~b}(21.07)$ \\
10 minutes & $14.01 \mathrm{~b}(15.38)$ & $39.31 \mathrm{a}(10.40)$ & $5.75 \mathrm{a}(33.10)$ & $12.32 \mathrm{a}(21.07)$ \\
12 minutes & $12.53 \mathrm{a} \mathrm{(14.32)}$ & $37.28 \mathrm{a}(7.59)$ & $5.50 \mathrm{a}(33.72)$ & $12.64 \mathrm{a}(25.33)$ \\
\hline CSA 0437* & & & 10,00 & \\
EN 300** & & & 15,00 \\
\hline
\end{tabular}

Means followed by the same letters in the same column are not statistically different according to Tukey's test at a $95 \%$ probability level. Coefficient of variation, in percentage, in parentheses. WA2h: Water absorption after 2 hours; WA24h: Water absorption after 24 hours; TS2h: Thickness swelling after 2 hours; TS24h: Thickness swelling after 24 hours. * Category R1: Panels with randomly aranged particles, ** OSB 3: Structural panels for use in wet conditions.

According to the results of Table 4, the panels that were thermally modified for 12 minutes exhibited the lowest mean values of water absorption after 2 hours and were statistically different from the other treatments. There was a decrease of $11.27 \%$ in relation to the treatment with 10 minutes of exposure.

For water absorption after 24 hours, the thermally modified panels presented statistically lower mean values in comparison with the control panels. There was a maximum decrease of $19.22 \%$ with thermal modification. For thickness swelling after 2 hours, no statistically significant differences were found between the mean values obtained for the thermally modified and the control panels.

The results of thickness swelling after 24 hours showed the effect of applying different times of thermal modification to improve said property, since the thermally modified panels presented statistically lower mean values in comparison with the control panels. There was a maximum decrease of $16.13 \%$ with thermal modification.

The results of water absorption and thickness swelling obtained for the different temperatures of thermal modification are exhibited in table 5 .

Table 5. Mean values of water absorption and thickness swelling for thermally treated panels at different temperatures.

Tabela 5. Valores médios de absorção de água e inchamento em espessura para painéis tratados termicamente a diferentes temperaturas.

\begin{tabular}{lllll}
\hline Temperature & $\begin{array}{l}\text { WA2h } \\
(\%)\end{array}$ & $\begin{array}{l}\text { WA24h } \\
(\boldsymbol{\%})\end{array}$ & $\begin{array}{l}\text { TS2h } \\
(\boldsymbol{\%})\end{array}$ & $\begin{array}{l}\text { TS24h } \\
(\boldsymbol{\%})\end{array}$ \\
\hline Control & $13.83 \mathrm{a} \mathrm{(10.66)}$ & $46.32 \mathrm{~b}(11.88)$ & $5.09 \mathrm{a}(28.47)$ & $14.60 \mathrm{~b}(21.07)$ \\
$180^{\circ} \mathrm{C}$ & $12.84 \mathrm{a}(15.94)$ & $36.84 \mathrm{a}(10.62)$ & $5.32 \mathrm{a}(25.30)$ & $13.12 \mathrm{~b}(20.93)$ \\
$200^{\circ} \mathrm{C}$ & $13.95 \mathrm{a}(16.39)$ & $38.20 \mathrm{a}(10.09)$ & $6.13 \mathrm{a}(32.57)$ & $13.71 \mathrm{~b}(21.22)$ \\
$220^{\circ} \mathrm{C}$ & $12.97 \mathrm{a} \mathrm{(16.01)}$ & $39.04 \mathrm{a}(12.96)$ & $5.93 \mathrm{a}(33.25)$ & $11.13 \mathrm{a}(25.17)$ \\
\hline
\end{tabular}

CSA $0437 *$

10.00

EN $300 * *$

15.00

Means followed by the same letters in the same column are not statistically different according to Tukey's test at a 95\% probability level. Coefficient of variation, in percentage, in parentheses. WA2h: Water absorption after 2 hours; WA24h: Water absorption after 24 hours; TS2h: Thickness swelling after 2 hours; TS24h: Thickness swelling after 24 hours. * Category R1: Panels with randomly arranged particles, ** OSB 3: Structural panels for use in wet conditions.

According to the results of Table 5, no significant effect was seen with the application of different temperatures of thermal modification on water absorption after 2 hours.

FLORESTA, Curitiba, PR, v. 51, n. 2, p. 419-428, abril/jun 2021. 
For water absorption after 24 hours, applying different temperatures of thermal modification had some effect. At all analyzed temperatures, the thermally modified panels exhibited lower mean values in comparison with the control panels. There was a maximum decrease of $20.46 \%$ with the thermal modification.

The results of thickness swelling after 2 hours presented no statistical difference between the panels thermally modified at different temperatures of thermal modification and control panels. For thickness swelling after 24 hours, the panels thermally modified at $220^{\circ} \mathrm{C}$ presented lower values, statistically differing from the other treatments. The difference in thickness swelling after 24 hours between the control panels and the panels thermally modified at $220^{\circ} \mathrm{C}$ was of $23.76 \%$.

The results of modulus of elasticity, modulus of rupture and internal bond of the panels subjected to different times of thermal modification are exhibited in Table 6.

Table 6. Mean values of modulus of elasticity, modulus of rupture and internal bond for panels subjected to different thermal modification times.

Tabela 6. Valores médios de módulo de elasticidade, módulo de ruptura e tração perpendicular à superfície dos painéis submetidos a diferentes tempos de modificação térmica.

\begin{tabular}{llll}
\hline Treatment & MOE (MPa) & MOR (MPa) & IB (MPa) \\
\hline Control & $2710 \mathrm{a}(17.92)$ & $22.69 \mathrm{a}(23.48)$ & $0.51 \mathrm{a}(20.35)$ \\
$10 \mathrm{~min}$ & $2554 \mathrm{a}(21.44)$ & $19.50 \mathrm{a}(19.34)$ & $0.52 \mathrm{a}(17.47)$ \\
$12 \mathrm{~min}$ & $2558 \mathrm{a}(22.48)$ & $21.02 \mathrm{a}(20.13)$ & $0.48 \mathrm{a}(13.93)$ \\
\hline CSA 0437* & 3040 & 16.87 & 0.34 \\
EN 300 parallel** & 3500 & 20.00 & 0.32 \\
EN 300 perpendicular** & 1500 & 10.00 & 0.40 \\
EN 312 & 1800 & 13.00 & \\
\hline
\end{tabular}

Means followed by the same letters in the same column are not statistically different according to Tukey's test at a $95 \%$ probability level. Coefficient of variation, in percentage, in parentheses. MOE: Modulus of elasticity; MOR: Modulus of rupture; IB: Internal bond * Category R1: Panels with randomly arranged particles, ** OSB 3: Structural panels for use in wet conditions.

The results presented in Table 6 indicate that the different times of thermal modification did not affect the mechanical properties of modulus of elasticity, modulus of rupture and internal bond significantly.

Table 7 exhibits the values of modulus of elasticity, modulus of rupture and internal bond of panels subjected to thermal modification at different temperatures.

Table 7. Mean values of modulus of elasticity, modulus of rupture and internal bond of panels subjected to different thermal treatment temperatures.

Tabela 7. Valores médios de módulo de elasticidade, módulo de ruptura e tração perpendicular à superfície dos painéis submetidos às diferentes temperaturas de modificação térmica.

\begin{tabular}{llll}
\hline Treatment & MOE $($ MPa) & MOR $(\mathbf{M P a})$ & IB $(\mathbf{M P a})$ \\
\hline Control & $2704 \mathrm{a}(17.92)$ & $22.63 \mathrm{a}(23.48)$ & $0.52 \mathrm{a}(20.35)$ \\
$180^{\circ} \mathrm{C}$ & $2419 \mathrm{a}(21.16)$ & $20.32 \mathrm{a}(20.70)$ & $0.52 \mathrm{a}(16.19)$ \\
$200^{\circ} \mathrm{C}$ & $2753 \mathrm{a}(24.10)$ & $21.72 \mathrm{a}(20.25)$ & $0.48 \mathrm{a}(14.12)$ \\
$220^{\circ} \mathrm{C}$ & $2499 \mathrm{a}(23.02)$ & $18.44 \mathrm{a}(25.25)$ & $0.51 \mathrm{a}(17.70)$ \\
\hline CSA 0437* & 3040 & 16.87 & 0.34 \\
EN 300 parallel ${ }^{* *}$ & 3500 & 20.00 & 0.32 \\
EN 300 perpendicular** & 1500 & 10.00 & 0.40 \\
EN 312 & 1800 & 13.00 & \\
\hline
\end{tabular}

Means followed by the same letters in the same column are not statistically different according to Tukey's test at a 95\% probability level. Coefficient of variation, in percentage, in parentheses. MOE: Modulus of elasticity; MOR: Modulus of rupture; IB: Internal bond * Category R1: Panels with randomly arranged particles, ** OSB 3: Structural panels for use in wet conditions.

The results presented in Table 7 indicate that the different temperatures of thermal modification did not affect the mechanical properties of modulus of elastic, modulus of rupture and internal bond significantly.

\section{DISCUSSION}

The fact that density and compaction ratio were not influenced by the thermal modification can be explained by the exposure times and applied temperatures, which were not able to reduce the density. According to Melo et al. (2018), this is a positive behavior because reducing the panels' density can decrease the final product's quality.

FLORESTA, Curitiba, PR, v. 51, n. 2, p. 419-428, abril/jun 2021 
The compaction ratio of all treatments was over 1.3. According to Maloney (1993), 1.3 is the minimum recommended value for compaction ratio if one wishes to obtain panels with a satisfactory contact area between the particles and sufficient densification to form the panel.

Regarding the normative requirements, both the panels thermally modified at different exposure times to thermal modification and the control panels achieved the values recommended by the CSA 0437 for thickness swelling after 2 hours and by the EN 300 for thickness swelling after 24 hours.

The average water absorption values of the Eucalyptus badjensis mixed particleboard / OSB panels thermally modified under different temperatures and exposure times were higher than those obtained by Rosa $e t$ al. (2017), whose mean values, for OSBs of five Eucalyptus species, were between $10.32 \%$ and $11.37 \%$ for water absorption after 2 hours and between $31.66 \%$ to $36.58 \%$ for water absorption after 24 hours. In comparison with the literature values for particleboards, the mean water absorption values were lower in comparison with those obtained by Cunha et al. (2014), whose mean values for Eucalyptus benthamii particleboard panels were of $15.9 \%$ and $39.9 \%$ for water absorption after 2 and 24 hours, respectively.

For thickness swelling, the Eucalyptus badjensis mixed particleboard / OSB panels of the present study exhibited greater results than those obtained by Rosa et al. (2017), whose values, for the OSB panels of five species of Eucalyptus, were between $2.09 \%$ and $2.46 \%$ for thickness swelling after 2 hours and between $8.56 \%$ and $10.44 \%$ for thickness swelling after 24 hours. In comparison with the literature's results for particleboard panels, the mean values obtained were lower than those obtained by Iwakiri et al. (2000), whose mean values, for particleboard panels of Eucalyptus grandis, were of $12.4 \%$ and $24.02 \%$ for thickness swelling after 2 and 24 hours, respectively.

Regarding normative requirements, the mixed particleboard / OSB panels of thermally modified Eucalyptus badjensis and the control panels obtained the values recommended by the CSA 0437 and the EN 300 for thickness swelling after 2 and 24 hours, respectively.

Generally, we noticed that the thermal modification affected the physical properties of the panels' water absorption and thickness swelling positively.

The thermal modification improves the dimensional stability properties because it releases the internal compression stress generated during the pressing stage and reduces the wood's hygroscopicity (DEL MENEZZI et al., 2009).

In turn, the reduction of the wood's hygroscopicity is related to the degradation of its most hydrophilic constituent: hemicellulose. Such degradation generates furfural and other less hygroscopic polymers (BATISTA et al., 2011).

According to Boonstra and Tjeerdsma (2006), the cellulose amorphous area degradation and the lignin crosslinks increase caused by polycondensation reactions also contribute to the reduction of wood's hygroscopicity.

Regarding the normative requirements, for the modulus of elasticity, the mixed Eucalyptus badjensis panels submitted to different times of thermal modification reached the values established by the EN 312 and EN 300 for the perpendicular direction. On the other hand, in comparison with the CSA 0437 and EN 300 for the parallel direction, no treatment obtained mean values that satisfied the standards' required values.

For modulus of rupture, the mixed Eucalyptus badjensis panels thermally modified under different times, presented mean values that met the CSA 0437, EN 312 and EN 300 normative requirements for the perpendicular direction. In comparison with the EN 300, for the parallel direction, only the panels submitted to thermal modification for 10 minutes presented mean values below the minimum values established by the EN 300 for the parallel direction.

For internal bond, the values of the panels subjected to different times of thermal modification satisfied the CSA 0437, EN 300 and EN 312 normative requirements. For the properties modulus of elasticity, modulus of rupture and internal bond, no statistically significant difference was found between the different thermal modification temperatures employed in the study.

The mean values of modulus of elasticity of the Eucalyptus badjensis mixed particleboard / OSB panels were higher in comparison with those obtained by Cunha et al. (2014), which was of 2049.3 MPa for Eucalyptus benthamii particleboards. In comparison with the results of Gorski et al. (2015), for Eucalyptus benthamii OSB panels, the mean values obtained for the mixed panels were lower for the parallel direction (4368.0 MPa) and higher for the perpendicular direction (1192.2 MPa).

For modulus of rupture, the thermally modified Eucalyptus badjensis mixed particleboard / OSB panels presented higher mean values in comparison with those obtained by Rios et al. (2015), whose mean value for Eucalyptus grandis particleboards was of $15.4 \mathrm{MPa}$. In comparison with the results obtained by Gorski et al. (2015) for Eucalyptus benthamii OSB panels, the mixed panels presented lower values for the parallel direction (26.6 MPa) and higher values for the perpendicular direction (15.3 MPa).

For internal bond, the Eucalyptus badjensis mixed particleboard / OSB panels presented mean values similar to those obtained by Rios et al. (2015), whose mean value for Eucalyptus grandis panels was of $0.54 \mathrm{MPa}$.

FLORESTA, Curitiba, PR, v. 51, n. 2, p. 419-428, abri1/jun 2021.

Pereira, G. F. et.al.

ISSN eletrônico 1982-4688

DOI: $10.5380 /$ rf.v51 i2. 69403 
In comparison with OSBs, the present study's results were similar to those obtained by Rosa et al. (2017), whose mean values for the OSB panels of five Eucalyptus species were between $0.45 \mathrm{MPa}$ and $0.56 \mathrm{MPa}$.

In comparison with the normative requirements, the Eucalyptus badjensis mixed particleboards / OSB panels thermally modified at different temperatures presented mean values that satisfied the EN 312 and EN 300 standards for the perpendicular direction, but did not reach the mean values recommended by the CSA 0437 and EN 300 for the parallel direction.

For the modulus of rupture and internal bond, the panels thermally modified at different exposure times satisfied the values established by the CSA 0437, EN 300 and EN 312 normative requirements.

The fact that the panels made out of Eucalyptus badjensis wood satisfied most of the normative requirements indicates this species' potential for the production of mixed particleboard / OSB panels.

Generally, the thermal modification did not affect the studied panels' mechanical properties modulus of elasticity, modulus of rupture and internal bond.

The effect of thermal modification varies according to the processing conditions (temperature, time, type of treatment) and the employed material (VERNOIS, 2000). An increase in time and/or temperature of thermal modification can affect the material's mechanical properties negatively, mainly due to mass loss (BOONSTRA; TJEERDSMA, 2006).

According to Vernois (2000), the mechanical properties of wood thermally modified at $210^{\circ} \mathrm{C}$ are similar to the original ones. However, said properties can be negatively affected if the treatment is carried out at temperatures above $230^{\circ} \mathrm{C}$.

The fact that thermal modification did not affect the panels' mechanical properties of the present study is related to exposure times and science. If the speeds were higher, the mass loss and the consequent degradation of the panels' mechanical properties could have occurred.

The results obtained in this study showed that the thermal modification, in terms of exposure times and temperatures employed, positively affect the dimensional stability properties, without compromising the mechanical resistance properties of the mixed particleboard / OSB panels. Notice that the mixed particleboard / OSB panels still have the best surface finishing, which is the result of using sliver particles in the outer layers and due to the greater property uniformity at different directions generated by the random particle arrangement.

\section{CONCLUSIONS}

- The thermal modification applied at different study times (10 minutes and 12 minutes) was effective to improve the dimensional stability of the mixed particleboard / OSB panels because it reduces the average values of water absorption after 2 and 24 hours and the thickness swelling after 24 hours.

- The 12-minute thermal modification period was the most effective to improve the panels' dimensional stability, mainly in the water absorption after 2 hours, which caused a reduction of $11.27 \%$ in comparison with the values obtained by the control panels.

- The increase in temperature of thermal modification improved the panels' dimensional stability, especially the thickness swelling after 24 hours of immersion, in which the treatment at $220^{\circ} \mathrm{C}$ caused a decrease of $23.76 \%$.

- The thermal modification in the temperatures and exposure times employed did not affect the mixed particleboard / OSB panels' mechanical properties.

- According to this study's objectives, the best thermal modification condition was obtained after 12 minutes of exposure time and at a temperature of $220^{\circ} \mathrm{C}$.

- The mixed particleboard / OSB panels presented average mechanical properties between particleboard and OSB, with the advantage of better surface finishing, in addition to good dimensional stability, which indicates their potential for external use under limited loads.

- Based on the results obtained, the Eucalyptus badjensis wood has the potential to produce mixed particleboards / OSB panels, since it mostly satisfied the CSA 0437, EN 300 and EN 312 normative requirements.

\section{ACKNOWLEDGMENTS}

This work was carried out with the support of the Coordination for the Improvement of Higher Education Personnel - Brazil (CAPES) - Financing Code 001.

The authors would like to thank the companies Klabin S/A and GPC for supplying the raw material used in this study.

FLORESTA, Curitiba, PR, v. 51, n. 2, p. 419-428, abril/jun 2021. 


\section{REFERENCES}

BATISTA, D. C; Retificação térmica, termorretificação, tratamento térmico, tratamento com calor ou modificação térmica. Ciência Florestal. Santa Maria, v. 29, n.1, p. 463-480, 2019.

BATISTA, D. C; TOMASELLI, I.; KLITZKE, R. C. Efeito do tempo e da temperatura de modificação térmica na redução do inchamento máximo da madeira de Eucalyptus grandis Hill ex Maiden. Ciência Florestal, v.21, n.3, p. 533-540, 2011.

BOONSTRA, M.J.; TJEERDSMA, B.F. Chemical analysis of heat-treated softwoods. Holz Roh-Werkst, v.64, n.1, p.203-212, 2006.

CARVAlHO, A. G.; MENDES, R. F.; OLIVEIRA, S. F.; MENDES, L. M. Effect of post-production heat treatment on particleboard from Sugarcane bagasse. Materials Research. V.18, n.1. 2015.

CUNHA, A. B.; LONGO, B. L.; RODRIGUES, A. A.; BREHMER, D. R. Produção de painéis de madeira aglomerada de Eucalyptus benthamii, Eucalyptus dunni e Eucalyptus grandis. Scientia forestalis. v.42, n. 102. 2014.

CROITORU, C.; SPIRCHEZ, C.; LUNGUlEASA, A.; CRISTEA, A.; ROATA, I. C.; POP, M. A.; BEDO, T.; STANCIU, E. M.; PASCU, A. Surface proprieties of termally treated composite wood panels. Applied Surface Science. v.418, p. 114-126. 2018.

DEL MENEZZI, C. H. S.; TOMASELLI, I.; OKINO, E. Y. A.; TEIXEIRA, D. E.; SANTANA, M. A. E. Thermal modification of consolidated oriented strandboards: effects on dimensional stability, mechanical properties, chemical composition and surface color. European Journal of Wood Products. V.67, p. 383-393. 2009.

EISFELD, C. L.; BERGER, R. Análise das estruturas de mercado das indústrias de painéis de madeira (Compensado, MDF e OSB) no estado do Paraná. Floresta. Curitiba, v. 42, n.1. p. 21-34, 2012.

GORSKI, L.; CUNHA, A. B.; RIOS, P. D. A.; TRIANOSKI, R.; FRANÇA, M. C.; ALMEIDA, C. C. F.; LONGO, B. L. Utilização da madeira de Eucalyptus benthamii na produção de painéis de partículas orientadas (OSB). Floresta. v.45, n.4, p. $865-874,2015$.

HIGA, R. C. V.; HIGA, A. R.; ALVES, E. C. Comportamento de progênies de Eucalyptus badjensis Beuzev. \& Welch em dois locais da Região Sul do Brasil. Boletim de Pesquisa Florestal. Colombo, n. 45, 2002.

IBÁ - INDUSTRIA BRASILEIRA DE ÁRVORES. Anuário estatístico 2019. 80p. 2019.

IWAKIRI, S.; CUNHA, A. B. C.; ALBUQUERQUE, C. E. C.; GORNIAK, E.; MENDES, L. M. Resíduos de serrarias na produção de painéis de madeira aglomerada de eucalipto. Scientia Agrária, v.1, n.1-2, p.23-28, 2000.

IWAKIRI, S.; VIANEZ, B. F.; WEBER, C.; TRIANOSKI, R.; ALMEIDA, V. C. Avaliação das propriedades de painéis aglomerados produzidos com resíduos de serrarias de nove espécies da Amazônia. Acta Amazonica. v.42, n.1, p. 59-64. 2012.

MACEDO, L. B.; AQUINO, V. B. M., WOLENSKI, A. R. V.; CHRISTOFORO, A. L.; LAHR, F. A. R.; Painéis híbridos de lâminas e partículas de madeira para uso estrutural. Ambiente Construído. Porto Alegre. v. 19, n. 3, p. 15-23, 2019.

MELO, R. R.; MUHL, M.; STANGERLIN, D. M.; ALFENAS, R. F.; RODOLFO JÚNIOR, F. Properties of particleboards submitted to heat treatments. Ciência Florestal. Santa Maria, v.28, n.2, p. 776-783, 2018.

MENDES, R. F.; BORTOLETTO JÚNIOR, G.; DE ALMEIDA, N. F.; SURDI, P. G.; BARBEIRO, I. N. Effect of thermal treatment on properties of OSB panels. Wood Science and Tecnology. v, 47, n 2, p. 243-256, 2013.

MOSLEMI, A. A. Particleboard. Illionis: Southern Illionis University, 1974. v. 2, 245 p.

PEREIRA, G. F.; RIOS, P. D. A.; BUSS, R.; VIEIRA, H. C.; GRUBERT, W.; CUNHA, A. B.; BELINI, U. L. Painéis de madeira aglomerada de Eucalyptus badjensis e Pinus spp. Scientia forestalis, v.45, n.114, p. 373-382, 2017.

REPELLIN, V.; GUYONNET, R. Evaluation of heat-treated wood swelling by differential scanning calorimetry in relation to chemical composition. Holzforschung, v. 59, n. 1, p. 28-34, 2005.

RIOS, P. D.; VIEIRA, H. C.; STUPP, A. M.; KNIESS, D. D. C.; BORBA, M. H.; CUNHA, A. B.; Avaliação física e mecânica de painéis reconstituídos compostos por partículas de galhos secos de Araucaria angustifolia

FLORESTA, Curitiba, PR, v. 51, n. 2, p. 419-428, abril/jun 2021. 
(Bertol.) Kuntze e madeira de Eucalyptus grandis Hill ex Maiden. Scientia Forestalis. Piracicaba, v. 43, n. 106, p. 283-289, jun. 2015.

ROSA, T. S.; TRIANOSKI, R.; IWAKIRI, S.; BONDUELLE, G. M. Utilização de Cinco espécies de Eucalyptus para a produção de OSB. Floresta e Ambiente. 2017.

SANTOS, P. E. T.; PALUDZYSZYN FILHO, E.; SILVA, L. T. M.; VANDRESEN, P. B. Genetic variation for growth and selection in adults plants of Eucalyptus badjensis. Genetics and Molecular Biology. v. 38, n.4, p. 457-464. 2015.

TRIANOSKI, R.; IWAKIRI, S.; MATOS, J. L. M.; CHIES, D. Utilização da madeira de Cryptomeria japonica para a produção de aglomerados. Scientia forestalis. V.41, n.97, p. 57-64, 2013.

THOEMEN, H.; IRLE, M.; SERNEK, M. Wood-Based Panel an Introduction for Specialists. Brunel University Press, Londres, 2010.

VERNOIS, M. Heat treatment of wood in France: state of the art. Paris: Nordic Wood. Centre Technique du Bois et de l'Ameublement. 2000. 